\title{
Economics and Business
}

Volume 1, Number 2, December 2018

http://journals.ums.ac.id/index.php/mijeb

\section{ECO-FRIENDLY CONSUMERS IN THE FOURTH INDUSTRIAL REVOLUTION: ACADEMIC SOCIETY, GREEN CUSTOMERS, AND ECO LABELLING}

\author{
Yanti Budiasih \\ STIE/ ITB Ahmad Dahlan Jakarta \\ Corresponding Author: yantibudiasih@yahoo.com
}

\begin{abstract}
This analytical descriptive research aims to find out the relationship between the investigated variables. These variables had been previously tested hence this study made several modifications. The data consisted of primary data and involved 150 students of Ahmad Dahlan Economics School as the respondents. The research variables were divided into exogenous variables (i.e., eco labeling, eco knowledge, green product, green packaging and green advertising) and endogenous variables (i.e., purchase intention and green customer). The data analysis technique was the Partial Least Square (PLS) by using SmartPls software. Based on the results of hypothesis testing, it can be concluded that: eco-knowledge has a significant negative influence on purchase intention; eco-knowledge has a significant negative influence on green customers; eco-labeling has a significant positive influence on purchase intention; eco-labeling has a significant negative influence on green customer; green product has a significant positive influence on purchase intention; green product has a significant positive influence on green customer; green packaging has an insignificant influence on purchase intention; green packaging has an insignificant influence on green customer; green advertising has a significant negative influence on purchase intention; green advertising has a significant positive influence on green customer; and purchase intention has a significant positive influence on green customer.
\end{abstract}

Keywords: Eco-labeling, eco-knowledge, green product, green packaging, green advertising, purchase intention, green customer

\section{Introduction}

Global warming is one of the most serious global challenges, in addition to other environmental issues such as ozone layer depletion and land, water, and air pollution. These issues are the impact of the industrial development. Human's mindset has altered from traditional/agricultural into industrial development. Accordingly, the reliance upon industrial aspects is strong. This change in mindset leads to the high reliance on industry and impacts on massive industrial development. In fact, it provides economic contribution which able to boost economic growth but also brings negative implication on the environment, including environmental pollution and global warming. Moreover, the augmentation of public consumption also contributes to environmental damage. According to Ardianti, Fahmi, and Ratnawati (2008), such damages lead to environmental degradation, which may not reach dangerous level yet has decreased the quality of the earth as the place of living spaces.

As the result of community dynamics, the adverse environmental impacts have raised people awareness about the importance of a safe and healthy environment. Such awareness has encouraged various elements of society to act based on their interest and concern for the environment. In general, consumers realize their interest and concern by purchasing or consuming 
eco-labeling products, namely environmentally friendly products in terms of material, production, distribution, marketing, and related business management. According to Harris (2006) in Paramita and Yasa (2015), people require producers for paying attention to marketing attributes, i.e., price, quality, promotion and supply, as well as producers' environmental concern. Arttachariya (2012) defines green customers as conscious individuals who are willing to buy environmentally friendly products and have more concern about health issues.

In responding the current environmental issues as well as new lifestyle and public awareness toward environmentally friendly products, producers attempt to create green products equipped with eco-labeling. It is a manifestation of their concern for the environmental issues in which every company is obliged to have an environmental responsibility. Moreover, there is a profitability (competitive) advantage in green products. The industrial concerns toward environmental challenges are indicated by the number of companies with certification to the ISO 14000 international standards on environmental management system.

Rex and Baumann (2007) in Muslim and Indriani (2014) define eco-label as a means for consumers to make choices for green products and inform them how products are made. This label also provides opportunities for companies to enter the market and gain market share. A good ecolabel program will examine the entire life cycle of a product that consists of production, distribution, utilization and disposal.

Furthermore, another element that has vital role in establishing or supporting ecolabeling or green products is the government and legislative assembly. The interests of parties directly involved in green products, including consumers and producers, can be accommodated by the government support through various law and regulations. Muslim and Indriani (2014) argued the responsiveness of Asian countries, i.e., China, Japan, Korea, India, Thailand, Malaysia, and Singapore, in addressing environmental issues. In fact, their governments encouraged the establishment of green marketing, which is realized through the issuance of eco-labeling for green products. Accordingly, these products are easily distinguished from ordinary products. Nevertheless, despite of the great potential of eco-labeling in Indonesia, its development was lethargic. Muslims and Indriani (2014) suggested that the Indonesian government should apply the eco-label certification for domestic green products in order to compete with imported products.

The phenomenon of environmentally friendly industry has been optimistically responded by many companies. PT Danone Aqua, for instance, replaces the entire material for labels and products on AQUA packaging, from polyvinyl chloride (PVC) into OPP made from PET and other biodegradable and recyclable materials (Gustyanita, 2013). The environmental awareness is also initiated by various companies, including retailers, markets and minimarkets, through the usage of environmentally friendly plastic bags. Despite the pros and cons regarding paid plastic bag, this movement also indicates the public awareness toward environmental sustainability through the existence of green products and packaging.

Currently, many companies begin to introduce and create green products. It is an effort for fostering the environmental awareness to increase customers' purchasing power (Okada \& Mais, 2010; Saxena \& Khandelwal, 2012). Basically, such awareness is distinguished into two, namely consumer perception and consumer reaction. Moreover, it is not only about understanding, but also the willingness and ability to purchase and promote green products. It also influences consumer purchase intention (Wu \& Chen, 2014) and environmental protection (Okada \& Mais, 2010 as cited in Santoso \& Fitriyani, 2016).

At one point, companies realize that environmental awareness and movement through eco-labeling or green products will not be abandoned by the community hence it will enhance the profitability. However, people will have concern about the importance of environmentally friendly products, even though the price is more expensive. Thus, companies should not be bothered since they are supported by green customers. Ščypa (2006) has a notion that green consumer is a consumer who constantly buys eco-friendly products and is actively concerned with environmental issues and solutions to them. Briefly, green consumers are a special market segment called green customers. According to Laroche, Bergeron \& Babaro-Forleo (2001), consumers who have environmental concern and knowledge about related issues generally become green consumers. 
Putra and Suryani (2016) reaffirmed Dehghanan and Bakhshandeh (2014) regarding the benefits of green products that positively influenced the purchase intention. Similarly, Muslim and Indriani (2014) revealed that the purchase intention was influenced by the trust in environmentally friendly products, knowledge about eco-labeling, and awareness toward ecolabeling and the availability of green products. Meanwhile, Santoso and Fitriyani (2016) disclosed that green packaging, green product and green advertising had a significant positive effect on consumer perception. Green products and perception had a significant positive effect on purchase intention, yet no plain evidence showed that green packaging and green advertising affected purchase intention. Furthermore, Yani and Astuti (2016) claimed that green marketing [advertising] influenced the decision to buy environmentally friendly products (organic products) in addition to the concerns for environment and health. Whereas Waskito and Witono (2014) concluded that the community's perception toward environmentally friendly products was shaped by regulation and image. In this context, purchase behavior is demonstrated by the campus consumption behavior towards environmentally friendly products.

Based on the background, the present study aims to investigate the eco-labeling and its effect on the establishment of green customer. As previous studies have discussed eco-labeling and related dimensions, i.e., green product, green advertising, green packaging, and variables of purchase interest and purchase decision, this study will focus on the significance of these variables in shaping green customer.

\section{Research Objectives}

Based on the background, the objectives of the present study are formulated as follows:

1. To analyze the influence of eco-knowledge on purchase intention;

2. To analyze the influence of eco-knowledge on green customers;

3. To analyze the influence of awareness on purchase intention;

4. To analyze the influence of awareness on green customer;

5. To analyze the influence of green product on purchase intention;
6. To analyze the influence of green product on green customer;

7. To analyze the influence of green packaging on purchase intention;

8. To analyze the influence of green packaging on green customers;

9. To analyze the influence of green advertising on purchase intention;

10. To analyze the influence of green advertising on green customer;

11. To analyze the influence of purchase intention on green customer.

\section{Research Method \\ Type of Research}

The present study is an analytical descriptive research which aim is to find out the relationships between variables. This study adopts variables that have been tested in previous studies after performing several modifications.

\section{Source of Data}

Based on the source of data, the present study used primary data in which the data was obtained directly through questionnaires. It involved the students of STIES Ahmad Dahlan Jakarta as the respondents in this study. The questionnaire consisted of closed-ended questions with a Linkert scale of 1 to 5. Closed-ended questionnaire limits the answers of the respondents to response options provided on it, without any opportunity to answer other alternatives.

\section{Research Sample}

According to Sugiyono (2013), in a multivariate research, the sample should be determined by multiplying the number of variables by 5 (five). Since the total variables in this study were 20 , the sample was at least 100 respondents. Several experts also suggest that in a study analyzed with a Structural Equation Modeling (SEM), at least 100 respondents must participate in it. Therefore, 100 respondents were involved in the present study.

\section{Research Variable}

In the present study, the variables were divided into exogenous variables and endogenous variables. The exogenous variables consisted of eco-labeling, eco-knowledge, green product, green 
packaging, and green advertising. Meanwhile, or construct between variables is presented in the the endogenous variables consisted of purchase following figure.

intention and green customer. The relationship

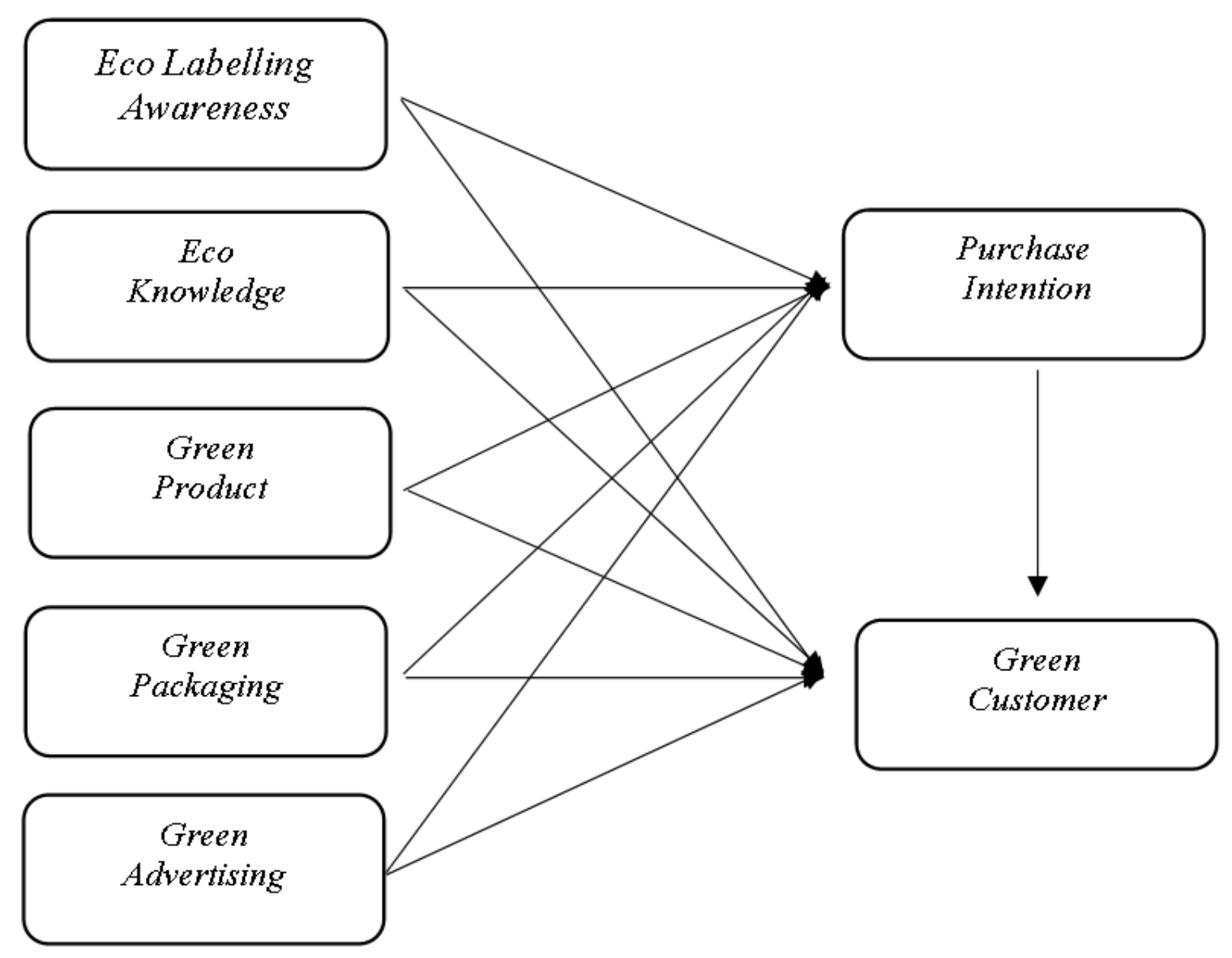

Figure 1. Construct and Variables

The description of the variables of this study is demonstrated in Table 1 below.

Table 1. Variables and Indicators

\begin{tabular}{|c|c|c|}
\hline \multirow[t]{4}{*}{$\begin{array}{l}\text { Eco-labeling aware- } \\
\text { ness }\end{array}$} & $\mathrm{X} 1$ & $\begin{array}{l}\text { Recognizing eco-label on environmentally friendly or green } \\
\text { products (Juwaheer \& Puraduth, 2012). }\end{array}$ \\
\hline & $\mathrm{X} 2$ & $\begin{array}{l}\text { Realizing the presence of eco-label on the products (Nguyen \& } \\
\mathrm{Du}, 2010 \text { ) }\end{array}$ \\
\hline & $\mathrm{X} 3$ & $\begin{array}{l}\text { Realizing the government has promoted the presence of eco-la- } \\
\text { bel (Nguyen \& Du, 2010) }\end{array}$ \\
\hline & $\mathrm{X} 4$ & $\begin{array}{l}\text { Recognizing the policy of eco-label to guide consumers toward } \\
\text { sustainable consumption (Nguyen \& Du, 2010) }\end{array}$ \\
\hline \multirow[t]{2}{*}{ Eco-Knowledge } & $\mathrm{X} 5$ & $\begin{array}{l}\text { Identifying laws and regulations concerning eco-labeling in In- } \\
\text { donesia (Nguyen \& Du, 2010) }\end{array}$ \\
\hline & $\mathrm{X} 6$ & $\begin{array}{l}\text { Recognizing that eco-label is label that identifies the preference } \\
\text { for environment of a product based on its life cycle (Nguyen \& } \\
\mathrm{Du}, 2010 \text { ) }\end{array}$ \\
\hline
\end{tabular}




\begin{tabular}{|c|c|c|}
\hline \multirow[t]{3}{*}{ Green Product } & $\mathrm{X} 7$ & $\begin{array}{l}\text { Green product has benefits for the environment (Pankaj \& } \\
\text { Vishal, 2014); }\end{array}$ \\
\hline & $\mathrm{X} 8$ & $\begin{array}{l}\text { Satisfaction toward the performance of green products (Kong et } \\
\text { al., 2015) }\end{array}$ \\
\hline & X9 & $\begin{array}{l}\text { Green products are made from non-hazardous materials (Santo- } \\
\text { so \& Fitriyani, 2016) }\end{array}$ \\
\hline \multirow[t]{4}{*}{ Green Packaging } & $\mathrm{X} 10$ & $\begin{array}{l}\text { Green packaging is biodegradable and recyclable (Rokka } \\
\text { \&Uusitalo, 2008); }\end{array}$ \\
\hline & $\mathrm{X} 11$ & Green packaging is reusable (Rundh, 2009); \\
\hline & $\mathrm{X} 11$ & $\begin{array}{l}\text { Green packaging is made from recycled materials (Draskovic et } \\
\text { al., 2009) }\end{array}$ \\
\hline & $\mathrm{X} 13$ & $\begin{array}{l}\text { Green packaging is made from non-hazardous materials (Santo- } \\
\text { so \& Fitriyani, 2016) }\end{array}$ \\
\hline \multirow[t]{2}{*}{ Green Advertising } & $\mathrm{X} 14$ & $\begin{array}{l}\text { Information in eco-label is understandable (Patel \& Chugan, } \\
\text { 2015); }\end{array}$ \\
\hline & $\mathrm{X} 15$ & $\begin{array}{l}\text { Information provided on eco-label is accurate ( } \mathrm{Wu} \& \text { Chen, } \\
2014)\end{array}$ \\
\hline \multirow[t]{3}{*}{ Purchase Intention } & Y1 & $\begin{array}{l}\text { The concern about the use of eco-label on environmentally } \\
\text { friendly products (Lefébure \& Muñoz, 2011) }\end{array}$ \\
\hline & Y2 & $\begin{array}{l}\text { Eco-label convinces consumers to buy eco-friendly products } \\
\text { (Nguyen \& } \mathrm{Du}, 2010 \text { ) }\end{array}$ \\
\hline & Y3 & $\begin{array}{l}\text { Intention to buy products with eco-label despite of their higher } \\
\text { price (Lefébure \& Muñoz, 2011) }\end{array}$ \\
\hline \multirow[t]{2}{*}{ Green Customer } & Y4 & The concern about the environmental sustainability \\
\hline & Y5 & The priority on environmentally friendly products \\
\hline
\end{tabular}

Sources: 1) Muslim and Indriani, 2014; 2) Santoso and Fitriyani, 2016; 3) Data processing, 2016

\section{Validity and Reliability Test}

Validity testing ensures the items within the questionnaire have reflected the dimensions to be measured. If the data retrieved from questionnaire using the Linkert scale is assumed as interval data, the validity test is done using the Pearson productmoment correlation coefficient. Meanwhile, if the data retrieved from questionnaire using the Linkert scale is assumed as ordinal data, it must be converted into the interval scale using the successive interval method (Algifari, 2015). Subsequently, since the data in the present study were interval data, validity testing was carried out through the Pearson product-moment correlation using SPSS. The items in the questionnaire are valid if the correlation coefficient of each variable is greater than 0.3 .

Subsequently, reliability testing was done to ensure that the information is reliable as a tool to collect data and is able to reveal the actual information in the field. Ghozali (2009) argues that reliability is a tool to measure a questionnaire which is an indicator of variables or constructs. A questionnaire is reliable if one's response to a statement is consistent or stable over time. The reliability of a test refers to the degree of stability, consistency, predictive validity, and accuracy. The higher the reliability of a test is, the more likely it produces reliable data. In the present study, to measure the validity and reliability of the instrument, SPSS was employed. The status of a questionnaire is indicated by Cronbach's alpha. It is reliable if the Cronbach's alpha is at least 0.6.

\section{Data Analysis Technique}

Data analysis is performed using SmartPLS software with the steps clarified as follows (Noor, 2015):

a. The design of inner/structural model

The inner model or structural model describes the relation between all constructs or latent variables corresponding to substantive theory. The design of structural model of the relation between latent variables is devised 
based on research hypotheses.

b. The design of outer/measurement model The outer model or measurement model defines how each block of indicators relates to its latent variable. The design of measurement model determines the nature of the indicators of each latent variable, whether reflective or normative, based on the operational definition of the variable.

c. The construction of a path diagram

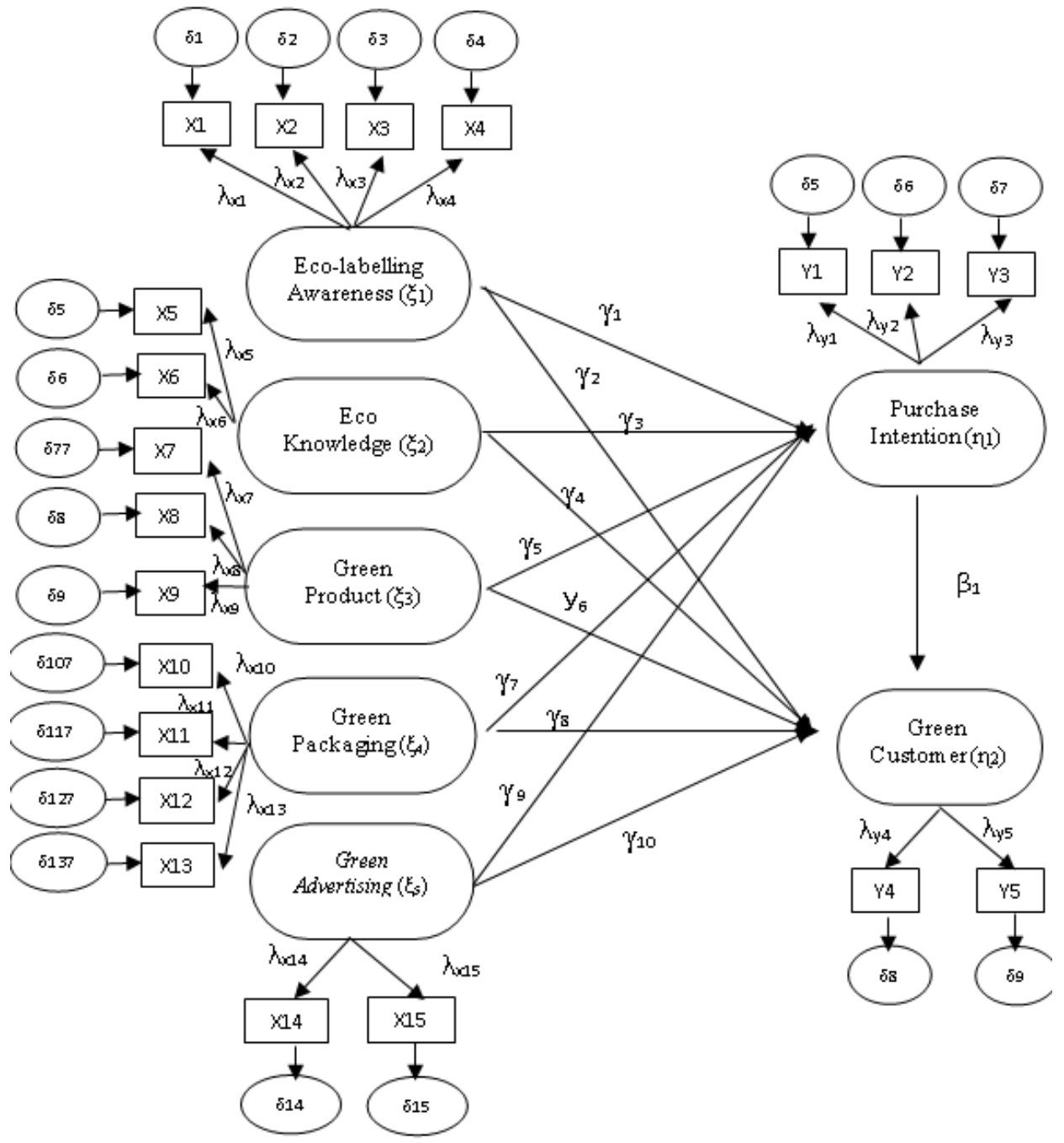

Figure 2. The Construct of Path Diagram

Description:

$\xi \quad=$ Ksi, exogenous latent variables

$\eta=$ Eta, endogenous latent variable

$\lambda \mathrm{x}=$ Lambda-x (parameter), loadings for exogenous variables

$\lambda y=$ Lambda-y (parameter), loadings for endogenous variables

$\Lambda \mathrm{x}=$ Lambda- $\mathrm{x}$ (matrix), loadings for exogenous variables

$\Lambda \mathrm{y}=$ Lambda-y (matrix), loadings for endogenous variables

$\beta=$ Beta (parameter) coefficient, the effect of exogenous variables on endogenous variables $\gamma=$ Gamma (parameter) coefficient, the effect of exogenous variables on endogenous variables

$\zeta=$ Zeta (parameter), error/disturbance

$\delta=$ Delta (parameter), measurement errors for exogenous variables

$\varepsilon=$ Epsilon (parameter), measurement errors for endogenous variable

d. Path diagram as an equation model

The basic equation for outer model can be written as follows:

- Reflective exogenous latent variable 1

$$
\mathrm{X}_{1}=\lambda_{\mathrm{x} 1} \xi_{1}+\delta_{1}
$$


$\mathrm{X}_{2}=\lambda_{\mathrm{x} 2} \xi_{1}+\delta_{2}$

$\mathrm{X}_{3}=\lambda_{\mathrm{x} 3} \xi_{1}+\delta_{3}$

$\mathrm{X}_{4}=\lambda_{\mathrm{x} 4} \xi_{1}+\delta_{4}$

- Formative exogenous latent variable 2

$\xi_{2}=\lambda_{x 5} X_{5}+\lambda_{x 6} X_{6}+\delta_{5}$

- Reflective endogenous latent variable 1

$\mathrm{y}_{1}=\lambda_{\mathrm{y} 1} \mathrm{\eta}_{1}+\varepsilon_{1}$

$\mathrm{y}_{2}=\lambda_{\mathrm{y} 2} \eta_{1}+\varepsilon_{2}$

$\mathrm{y}_{3}=\lambda_{\mathrm{y} 3} \eta_{1}+\varepsilon_{3}$

- Formative endogenous latent variable 2

$\mathrm{y}_{4}=\lambda_{\mathrm{y4}} \mathrm{\eta}_{2}+\varepsilon_{4}$

$\mathrm{y}_{5}=\lambda_{\mathrm{y} 5} \mathrm{\eta}_{2}+\varepsilon_{5}$

Furthermore, the basic equation for the inner model can be written as follows:

$\eta_{1}=\gamma_{1} \xi_{1}+\gamma_{2} \xi_{2}+\gamma_{3} \xi_{3}+\gamma_{4} \xi_{4}+\gamma_{5} \xi_{5}+\gamma_{6} \xi_{6}+\gamma_{7} \xi_{7}$ $+\gamma_{8} \xi_{8}+\gamma_{9} \xi_{9}+\gamma_{10} \xi_{10}+\zeta_{1}$

$\eta_{2}=\beta \eta_{1}+\gamma_{2} \xi_{2}+\gamma_{4} \xi_{4}+\gamma_{6} \xi_{6}+\gamma_{8} \xi_{8}+\gamma_{10} \xi_{10}+\zeta_{2}$

e. Estimation of path coefficient, loading and weight

The parameter estimation method in Partial Least Square (PLS) is the least square method. The estimation is done by iteration in which it is stopped right after the convergence criterion has been reached. The procedure comprises three main steps, namely:

1) The estimation of the weights to estimate the latent variable data;

2) The estimation of the path coefficient which indicates the correlations between latent variables and the estimation of loadings between latent variables and their indicators;

3) The determination of means and location parameters (the constant in regression, intercept) for indicators and latent variables

\section{f. Evaluation of goodness of fit}

Goodness of fit index is measured using the determination coefficient $\left(\mathrm{R}^{2}\right)$ of the dependent latent variables with the same interpretation as regression analysis. The predictive relevance $\left(\mathrm{Q}^{2}\right)$ for structural model measures the quality of the observation generated by the model and the estimation of the parameter $\left(\mathrm{R}^{2}\right)$.

$\mathrm{Q}^{2}=1-\left(1-\mathrm{R}_{1}^{2}\right)\left(1-\mathrm{R}_{2}^{2}\right) \ldots\left(1-\mathrm{R}_{\mathrm{p}}^{2}\right)$
The values range between $0<>2$ in the path analysis, where:

- $\mathrm{R}_{1}^{2}, \mathrm{R}_{2}^{2} \ldots \mathrm{R}_{\mathrm{p}}^{2}$ are $\mathrm{R}$-square values for endogenous variables in the model.

- The predictive relevance $\left(\mathrm{Q}^{2}\right)$ is interpreted similarly to the total coefficient of determination in the path analysis ( $\mathrm{R}^{2}$ in the regression analysis).

g. Bootstrap hypothesis testing

Hypothesis testing ( $\beta, \gamma$, and $\lambda$ ) was done by the bootstrap resampling technique developed by Geissers and Stone. The test statistics used t-statistic or t-test. Resampling technique allows the data distribution free in which it does require neither a normal assumption nor large samples (a minimum sample of 30 is recommended). Testing was done by t-test, statistically significant as $p$-value $\leq 0.05$.

- Statistical hypothesis for outer model:

$$
\begin{aligned}
& \mathrm{H} 0: \lambda \mathrm{i}=0 \\
& \mathrm{H} 1: \lambda \mathrm{i} \# 0
\end{aligned}
$$

- Statistical hypothesis for inner model: the effect of exogenous latent variables on endogenous variable

$$
\mathrm{H} 0: \gamma \mathrm{i}=0
$$$$
\mathrm{H} 1: \gamma \mathrm{i} \# 0
$$

- Statistical hypothesis for structural model: the effect of exogenous latent variables on endogenous variable $\mathrm{H} 0: \beta \mathrm{i}=0$ $\mathrm{H} 1: \beta \mathrm{i} \# 0$

\section{RESERACH RESULTS \\ Profile of Respondents}

The present study involved 150 students of STIE Ahmad Dahlan Jakarta from assorted majors who were selected incidentally as the respondents. They consisted of both male and female. Based on the results of the questionnaires, the respondents consisted of 108 female respondents ( 72 percent) and 40 male students (27 percent). Meanwhile, based on the major of study, 79 respondents (53 percent) were management students (including from D3 banking finance) and 56 respondents (48\%) were accounting students (including D3 accounting).

The respondents also ranged from freshmen (first semester) to senior (final semester) and the proportion was dissimilar since the respondents were chosen incidentally. However, these respondents were assumed to represent each group 
of year even though the number was limited. Based on this classification, 19 respondents (13 percent) were freshmen (1st semester), 58 respondents (39 percent) were senior students (6th semester), 34 respondents ( 23 percent) were sophomores (3rd semester), and 3 students ( 2 percent) were junior student (5th semester). In overall, the respondents were dominated by students in odd semester because this data was done in odd semester.

The age of the respondent was not questioned in the questionnaire, yet the range of the age of university students is identified, i.e., 18-23. It can be assumed that the respondents are adults and educated people. These characteristics certainly affect respondents' knowledge and responses to the questions.

\section{Descriptive Analysis}

In the present study, there are seven variables with twenty indicators as described in the research methodology. The variables are divided into exogenous variables and endogenous variables. Exogenous variables include eco-labeling awareness, eco-knowledge, green product, green packaging, and green advertising. Meanwhile, endogenous variables consist of purchase intention and green customer. The respondent's answers for each variable and indicator that has been submitted through the questionnaire with Linkert scale from 1 to 5 are elaborated below.

\section{a. Eco-Labeling Awareness}

Eco-labeling or the label of environmentally friendly products is one indicator to identify green product. From the label of a product, it can be a sort of information whether a product is environmentally friendly or not. Ecolabeling awareness is a public or consumer awareness of the label on environmentally friendly products. To what extent people recognize and realize the presence of environmentally friendly products is figured out from this variable through several indicators. There are four indicators in this variable, namely: [1] The respondent is aware of the presence of eco-label on green products, [2] The respondent is aware of ecolabel on green products during shopping, [3] The government supports the presence of eco-label, and [4] Eco-label is used as a policy tool to educate the public about the importance of environmental awareness.

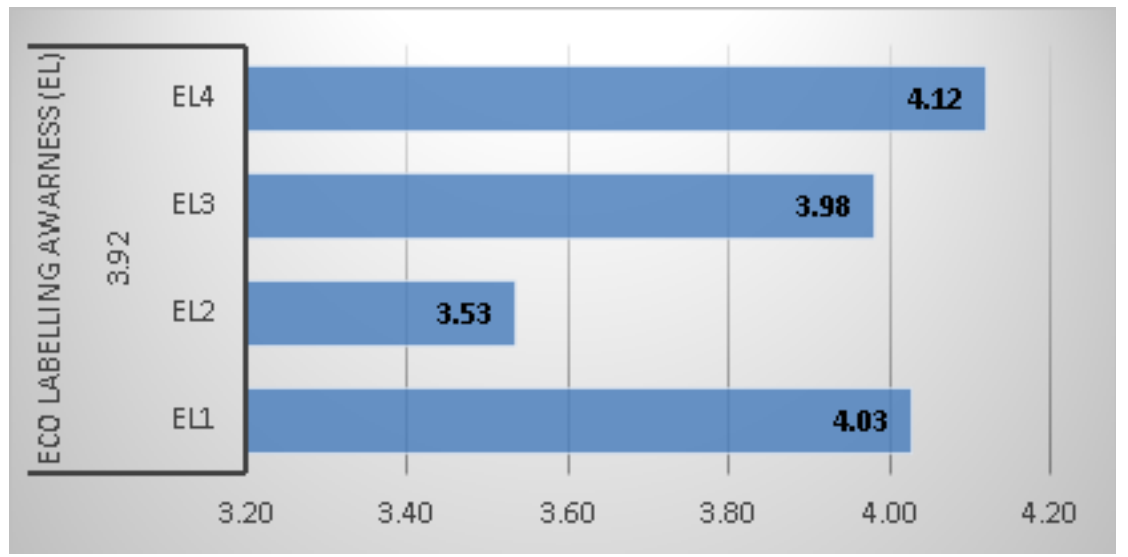

Figure 3. Score of Eco-labeling Awareness

EL1 $=$ Having awareness of the presence of eco-label on green products.

EL2 $=$ Having awareness of the presence of eco-label during shopping.

EL3 = Having awareness of the support of the government on eco-label.

EL4 $=$ Having awareness of eco-label as a policy tool to guide consumers toward a sustainable consumption.
Figure 3 shows that the respondents are aware about the presence of eco-label on green products as indicated by the score for the variable of eco-labeling awareness of 3.9. The highest average score obtains by EL4, namely the government policy in guiding consumers about environmentally friendly products through eco-label. Meanwhile, the lowest score obtains by EL2, namely the awareness of eco-label on particular products during shopping. It implies that in 
general, people are unaware of eco-label on green products. They are inclined to focus on common attributes when selecting or purchasing goods, e.g., price and quality.

b. Eco-knowledge

Eco-knowledge is a fundamental factor in the establishment of green consumers. In the present study, the variable of eco-knowledge is intended to identify respondent's knowledge about green products. There are two indicators in this variable, i.e., knowledge about ecolabel related regulations in Indonesia and identification of environmental preferences for a product based on its life cycle.

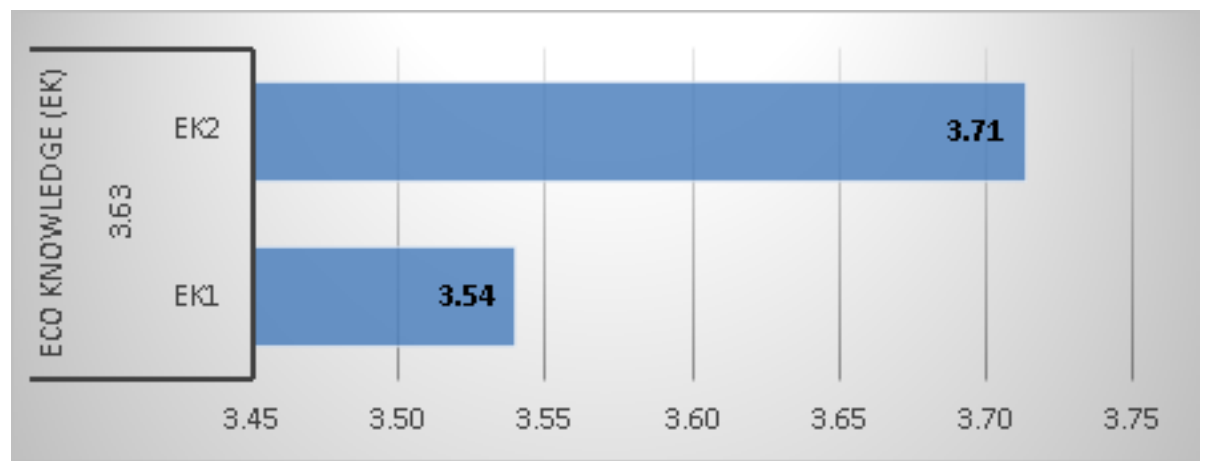

Figure 4. Score of Eco-knowledge

EK1 = Knowing the regulations related with eco-label in Indonesia.

EK2 = Knowing eco-label is label that identifies the environmental preferences of a product based on its life cycle (Nguyen \& Du, 2010).

Based on the assessment of the questionnaire results, the average score for the variable of eco-knowledge is 3.6. It indicates that in general, people have access for information or knowledge about environmentally friendly products and related regulations in Indonesia. Moreover, the score of ecoknowledge about the identification of environmental preferences for a product based on its life cycle is higher than the knowledge about eco-label related regulations in Indonesia.

c. Green Product

Green product is often identified as a product, which entails both content and packaging, with environmentally friendly quality. Nevertheless, in the present study, the scope of green product is limited to merely the content and not the packaging. There are three indicators to determine the extent of respondents' perceptions toward green products. These indicators relate to the benefits of green products on the environment, the satisfaction toward the performance of the products, and the use of non-hazardous raw materials. The score for these indicators is resented in Figure 5 below.

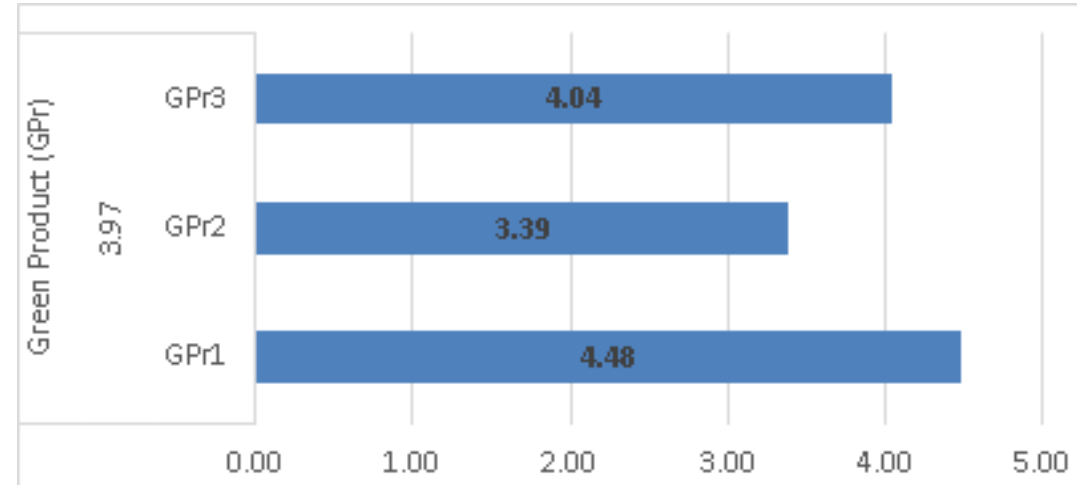

Figure 5. Score of Green Product 
GPr1 = Green product has benefits for the environment.

GPr2 = The performance of green product is satisfying.

GPr3 = Green products are made from non-hazardous materials.

In overall, the score of respondents' perceptions toward green products is 3.9, which is relatively high. It indicates that consumers agree that green products are environmentally friendly, the currentavailable green products have met the expectations of the consumers, and green products are entirely made from non-hazardous materials. The highest score obtains by indicator 1 (GPr1) of 4.48, which is the environmentally friendly properties of green products. The second indicator (GPr2) obtains the lowest score of 3.3. Nevertheless, the range of these scores is "good". The consumers agree that the current green products have fulfilled their expectations. Meanwhile, the third indicator
(GPr3) obtains a score of 4.0, implying the consumers agree that green products are made from non-hazardous materials.

d. Green Packaging

The variable of green product is only focused on the content/substance of the product and not the packaging. Its packaging is discussed as the variable of green packaging or environmentally friendly packaging, which is non-hazardous or for both humans and the environment. Green packaging is identified from the preference for its raw material, i.e., biodegradable materials. In addition, green packaging is examined from the technique used by the producers in creating it. The materials must not be retrieved from raw materials and/or processes that may damage the environment.

There are four indicators in this variable, i.e., recyclable packaging, reusable packaging, packaging is made from recycled materials, and packaging is made from non-hazardous materials.

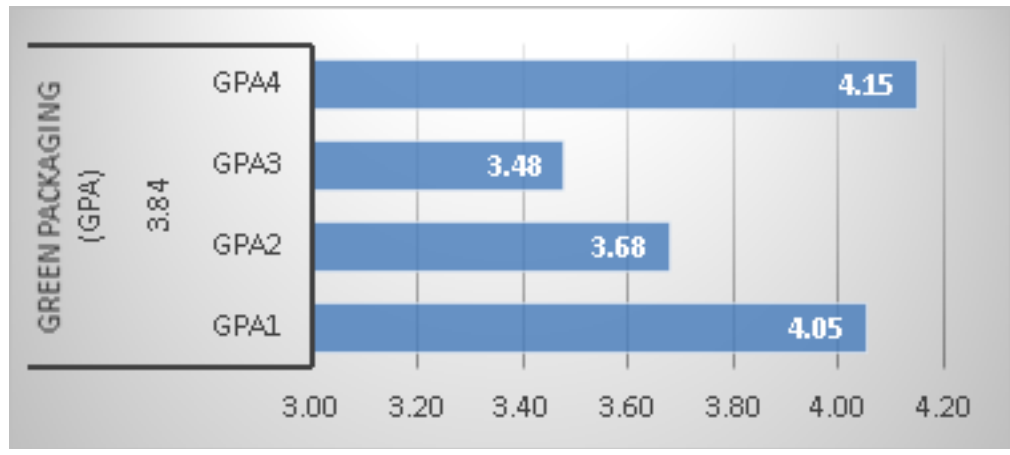

Figure 6. Score of Green Packaging

GPA1 = Recyclable packaging

GPA2 = Reusable packaging

GPA3 = Packaging is made from recycled materials

GPA4 $=$ Packaging is made from nonhazardous materials.

The average score for the first indicator (GPA1) is 4.0. It implies that the customers agree or notice about the characteristic of green packaging, i.e. recyclable. Such packaging can be directly reused and later, reprocessed without harming the environment. The second indicator (GPA2) obtains a score of 3.68, which indicates the customers agree that the green packaging is a product that can be reused for other needs, directly or indirectly. The third indicator also has the same score or perception, even though it has a low score (3.4) in which respondents agree that the packaging of green product is created from recycled materials. Moreover, they also notice that green packaging is a package made from non-hazardous materials (GPA4) as indicated by the score for this indicator, which is 4.1 .

e. Green Advertising

As a package, green products are a comprehensive, complete and thorough entity that must reflects its environmentally friendly attributes, from upstream to downstream. It covers the source or raw 
material, the technique to obtain and produce it, the marketing method, and the advertising strategy. Green products should be promoted in particular ways by involving environmentally friendly materials, and must not damage the environment. There are two indicators used in the variable of green advertising, i.e., the eco-label on green products is understandable and the eco-label on green products is accurate. The results on the respondents' perceptions show the average score of 3.6

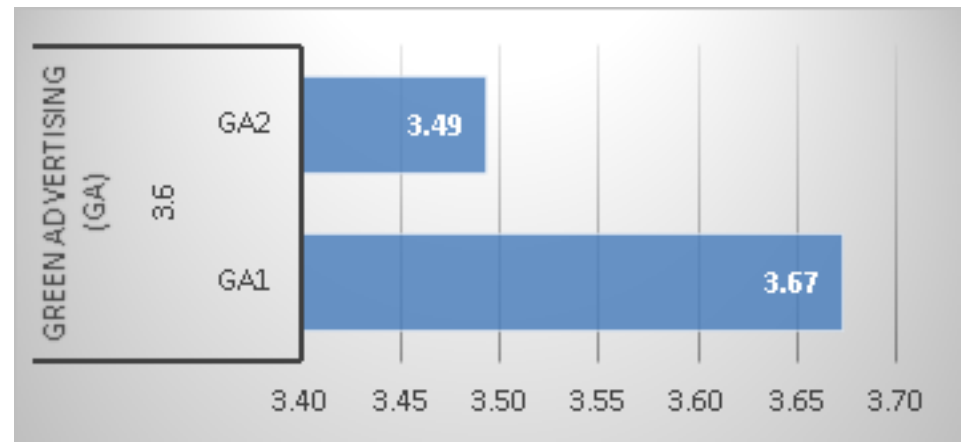

Figure 7. Score of Green Advertising

The score of the first indicator (GA1) is 3.7, implying the customers agree if the information submitted on the eco label is understandable. Such information can be obtained from signs or other information conveyed in the product. Similar to the first indicator, the second indicator (GA2) also shows that the customers agree that the information conveyed in the packaging or other forms of information on the eco-label is not only understandable, but also accurate. It can be seen from the average score for this second indicator of 3.5.

f. Purchase Intention

Purchase intention is the endogenous variable in this study in which it can be influenced by other variables. Purchase intention, as explained in the previous chapter, is an act that encourages people to buy something. In this study, it refers to the intention to buy environmentally friendly or green products as shown on the label or information conveyed by the product. Hence, this variable will examine whether the customer has the intention to buy a product if there is information or eco-label on that product. There are three indicators for this variable, i.e., concern for eco label products (PI1 or Y1), customers are convinced by eco-label (PI1 or Y2), and customers will buy products with eco-label despite of its higher price (PI1 or Y3). The result shows that most customers agree or intend to buy products with ecolabel. In overall, the score for this variable is 3.8 .

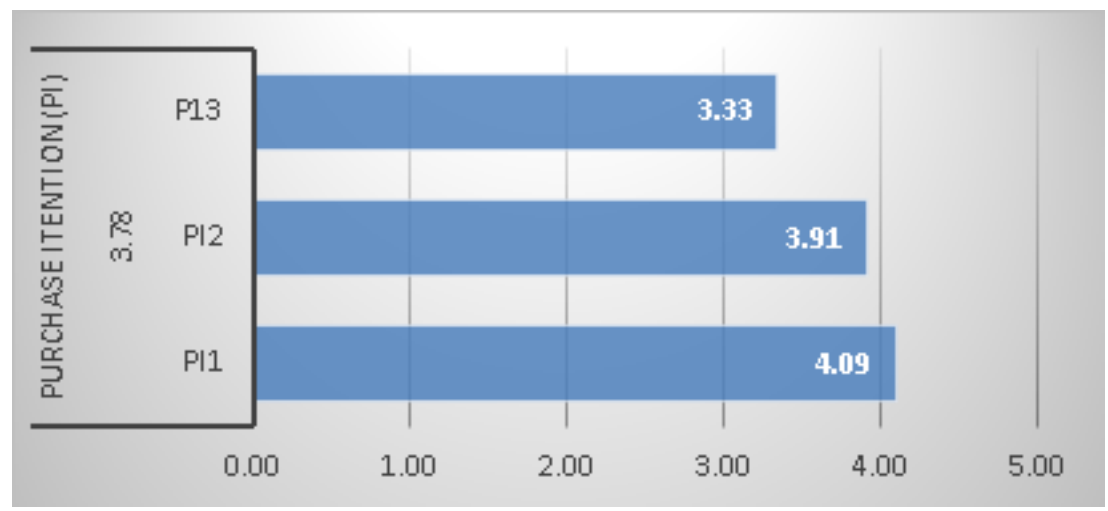

Figure 8. Score of Purchase Intention 
The average score of the first indicator (PI1) for purchase intention is 4.1. It indicates that the customers have concern about eco-label or information on green product. Likewise, based on the scores of the second and third indicators, the customers agree that ecolabels relatively convince them to buy green products and will still prefer such products even though the price is more expensive than similar products but without any eco-label. The average scores for the second a third indicators are 3.1 and 3.9, respectively.

\section{g. Green Customer}

Green customer is the endogen variable that shows the characteristics of green consumers or environmentally friendly consumers. Green consumers are those who have concern for the environment and its sustainability. When buying goods or products, they will consider their impact on the environment. They only prefer products that are safe or harmless to the environment. The indicators for this variable include the concern for a sustainable environment and the priority for purchasing environmentally friendly products.

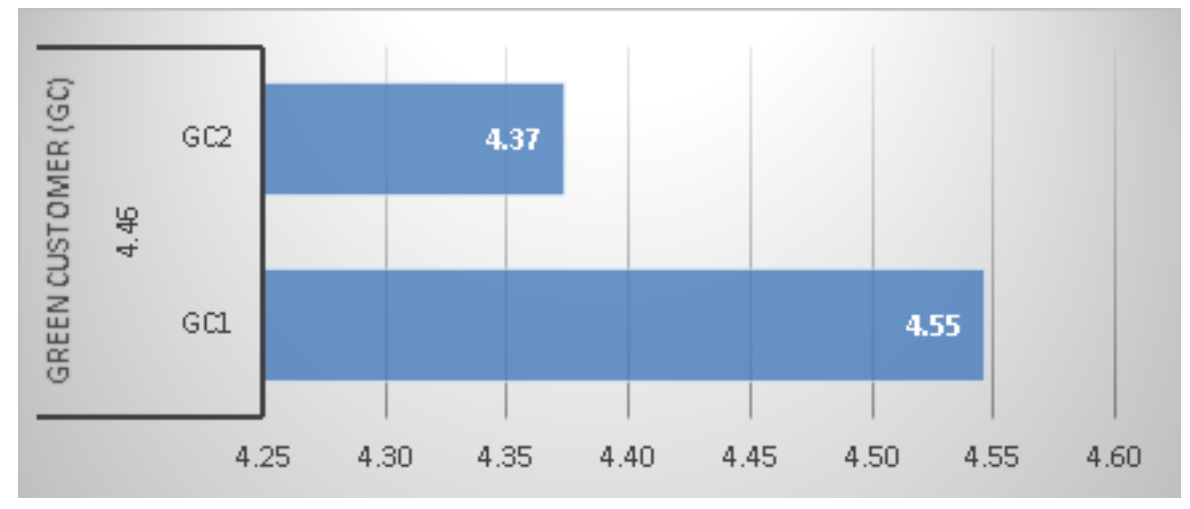

Figure 9. Score of Green Costumer

In overall, the score for the variable of green customer is quite high, which is 4.5 . It indicates that the customers can be called as green customers who have serious concern on environmental sustainability and will prioritize environmentally friendly products. The score for the first indicator ( $\mathrm{GCl}$ or $\mathrm{Y} 4$ ) is 4.5 , which indicates they strongly agree about environmental sustainability. Meanwhile, the second indicator (GC2 or Y5) obtains a score of 4.4. Similarly, it indicates that the customers strongly agree or will prioritize environmentally friendly products.

\section{A Quantitative Analysis}

To test the predetermined hypotheses, a partial least square structural equation modeling (PLSSEM) analysis was carried out using SmartPLS version 3.2.7. The result of data processing using this software is illustrated in the following structural model: 
Yanti Budiasih - Eco Friendly Consumer...

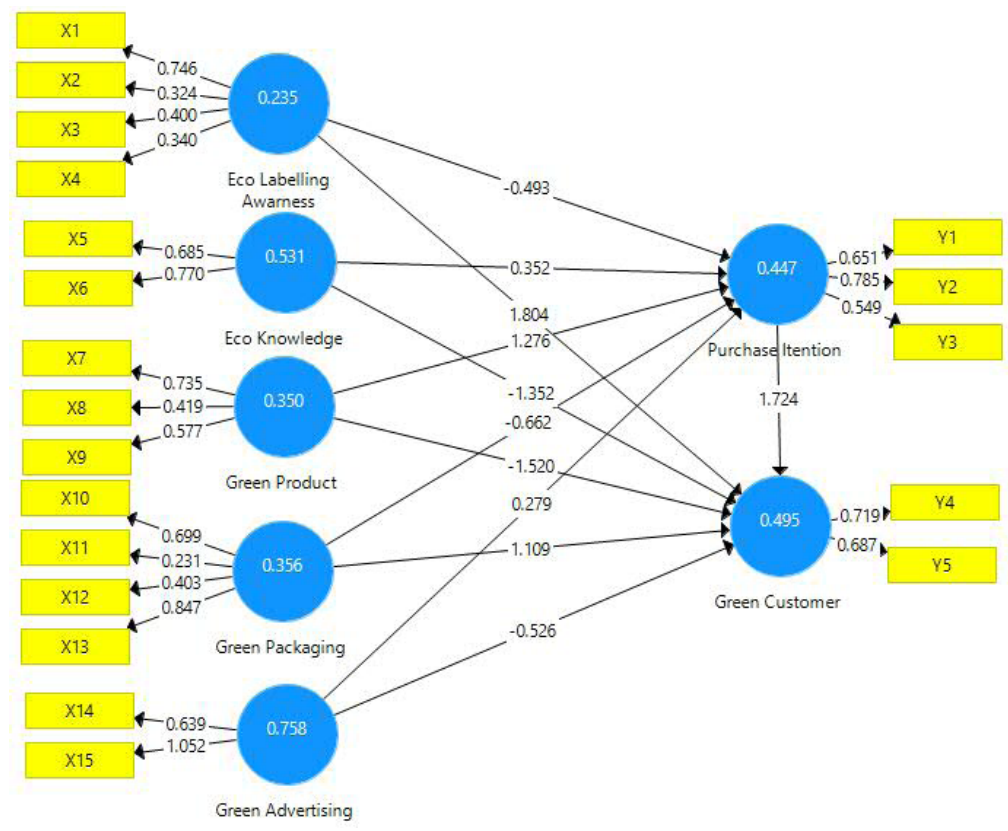

Figure 10. The Structural Model

The output statistically explains the relationship between latent variables and indicators as detailed as follows:

Table 1. Outer Model (Weights of Loading)

\begin{tabular}{|c|c|c|c|c|c|c|c|}
\hline & $\begin{array}{c}\text { Eco Labeling } \\
\text { Awareness }\end{array}$ & $\begin{array}{c}\text { Eco } \\
\text { Knowledge }\end{array}$ & $\begin{array}{c}\text { Green } \\
\text { Product }\end{array}$ & $\begin{array}{c}\text { Green } \\
\text { Packaging }\end{array}$ & $\begin{array}{c}\text { Green } \\
\text { Advertising }\end{array}$ & $\begin{array}{l}\text { Purchase } \\
\text { Intention }\end{array}$ & $\begin{array}{c}\text { Green } \\
\text { Customer }\end{array}$ \\
\hline $\mathrm{X} 1$ & 0.746 & & & & & & \\
\hline $\mathrm{X} 2$ & 0.324 & & & & & & \\
\hline $\mathrm{X} 3$ & 0.400 & & & & & & \\
\hline $\mathrm{X} 4$ & 0.340 & & & & & & \\
\hline X5 & & 0.685 & & & & & \\
\hline X6 & & 0.770 & & & & & \\
\hline X7 & & & 0.735 & & & & \\
\hline X8 & & & 0.419 & & & & \\
\hline X9 & & & 0.577 & & & & \\
\hline $\mathrm{X} 10$ & & & & 0.699 & & & \\
\hline X11 & & & & 0.231 & & & \\
\hline $\mathrm{X} 12$ & & & & 0.403 & & & \\
\hline $\mathrm{X} 13$ & & & & 0.847 & & & \\
\hline X14 & & & & & 0.639 & & \\
\hline X15 & & & & & 1.052 & & \\
\hline Y1 & & & & & & 0.651 & \\
\hline $\mathrm{Y} 2$ & & & & & & 0.785 & \\
\hline $\mathrm{Y} 3$ & & & & & & 0.549 & \\
\hline Y4 & & & & & & & 0.719 \\
\hline Y5 & & & & & & & 0.687 \\
\hline
\end{tabular}


Subsequently, the inner model is tested by determining the predictive relevance or Q2. To calculate Q2, the equation is stated as follows:

$\mathrm{Q}^{2}=1-\left(1-\mathrm{R} 1^{2}\right)\left(1-\mathrm{R} 2^{2}\right)$

$=1-(1-0.67)(1-0.715)=0.90595$
The result of predictive relevance $\left(\mathrm{Q}^{2}\right)$ is greater than 0.05 , it can be stated that it has met the requirements for further testing, namely the hypothesis testing.

Table 2. The Output of Hypothesis Testing

\begin{tabular}{|c|c|c|c|c|c|}
\hline & Original Sampl... & Sample Mean (... & Standard Devia... & T Statistics $(\mid \mathrm{O} \ldots$ & $P$ Values \\
\hline Eco Knowledge -> Green Customer & -0.03 & -0.04 & 0.12 & 0.29 & 0.78 \\
\hline Eco Knowledge $\rightarrow$ Purchase Itention & 0.03 & 0.02 & 0.10 & 0.33 & 0.74 \\
\hline Eco Labelling Awarness -> Green Customer & 0.28 & 0.26 & 0.12 & 2.34 & 0.02 \\
\hline Eco Labelling Awarness -> Purchase Itenti... & -0.06 & -0.06 & 0.09 & 0.63 & 0.53 \\
\hline Green Advertising -> Green Customer & -0.09 & -0.09 & 0.10 & 0.92 & 0.36 \\
\hline Green Advertising $\rightarrow$ Purchase Itention & 0.44 & 0.45 & 0.10 & 4.54 & 0.00 \\
\hline Green Packaging $>$ Green Customer & 0.20 & 0.19 & 0.12 & 1.70 & 0.09 \\
\hline Green Packaging $\rightarrow$ Purchase Itention & 0.14 & 0.15 & 0.12 & 1.12 & 0.26 \\
\hline Green Product $->$ Green Customer & 0.22 & 0.20 & 0.11 & 2.00 & 0.05 \\
\hline Green Product $\rightarrow$ Purchase Itention & 0.29 & 0.28 & 0.09 & 3.32 & 0.00 \\
\hline Purchase Itention -> Green Customer & 0.30 & 0.31 & 0.13 & 2.31 & 0.02 \\
\hline
\end{tabular}

Source: Data, processed

1. To determine the effect of eco-knowledge on both purchase intention and green customer, the hypotheses are developed as follows:

H1 : Eco-knowledge affects the purchase intention

$\mathrm{H} 2$ : Eco-knowledge affects the establishment of green customer

In accordance with Table 2, the $p$-value of $\mathrm{H} 1$ is 0.78 and $\mathrm{H} 2$ is 0.7 thus it can be stated that: Eco-knowledge has a significant negative effect on purchase intention and similarly, eco-knowledge has a significant negative effect on green customer.

2. To determine the effect of eco-labeling on purchase intention and the effect of ecolabeling on green customer, the hypotheses are developed as follows:

H3 : Eco-labeling affects purchase intention $\mathrm{H} 4$ : Eco-labeling affects green customer Table 4.2 demonstrates $p$-value of $\mathrm{H} 3$ is 0.02 and $\mathrm{H} 4$ is 0.53 . Therefore, it can be stated that eco-labeling has a significant positive effect on purchase intention and eco-labeling has a significant negative effect on green customer.

3. To determine the effect of green product on purchase intention and the effect of green product on green customer, the hypotheses are developed as follows:

H5 : Green product affects purchase intention
H6 : Green product affects green customer As shown on Table 4.2, the $p$-value of $\mathrm{H} 5$ is 0.05 and of $\mathrm{H} 6$ is 0.00 . It can be interpreted that green product has a significant positive effect on purchase intention. Likewise, green product also has a significant positive effect on green customer.

4. To determine the effect of green packaging on purchase intention and the effect of green packaging on green customer, the hypotheses are developed as follows:

H7 : Green packaging affects purchase intention

H8 : Green packaging affects green customer Table 4.2 demonstrates that the $p$-value of $\mathrm{H} 7$ is 0.09 and of $\mathrm{H} 8$ is 0.26 . It indicates that green packaging has an insignificant effect on purchase intention and green packaging has an insignificant effect on green customer.

5. To determine the effect of green advertising on purchase intention and the effect of green advertising on green customer, the hypotheses are developed as follows:

H9 : Green advertising affects purchase intention

H10 : Green advertising affects green customer

The effect of the variable of green advertising is shown by $p$-value in Table 4.2. The $p$-value 
of H9 is 0.36 and of H10 is 0.00 . Therefore, it can be claimed that green advertising has a significant negative effect on purchase intention. On the contrary, green advertising has a significant positive effect on green customer.

6. To determine the effect of endogenous variable, i.e., purchase intention, on green customer, the hypothesis is developed as follows:

H11 : Purchase intention affects green customer

The $p$-value of $\mathrm{H} 11$ is 0.02 . It indicates purchase intention has a significant positive effect on green customer.

\section{Conclusion}

Based on the findings of this study, it can be concluded that:

1. Eco-knowledge has a significant negative impact on purchase intention.
2. Eco-knowledge has a significant negative impact on green customer.

3. Eco-labeling has a significant positive impact on purchase intention.

4. Eco-labeling has a significant negative impact on green customer.

5. Green product has a significant positive impact on purchase intention.

6. Green product has a significant positive impact on green customer.

7. Green packaging has an insignificant impact on purchase intention.

8. Green packaging has an insignificant impact on green customer.

9. Green advertising has a significant negative impact on purchase intention.

10. Green advertising has a significant positive impact on green customer.

11. Purchase intention has a significant positive impact on green customer.

\section{References}

Ardianti, N., T., Fahmi, I., \& Ratnawati, A. (2008). Analisis perilaku konsumen Bogor terhadap produk kosmetik hijau. Jurnal Manajemen \& Agribisnis, 5(1), 16-22.

Paramita, N. D., \& Yasa, N. N. K. (2015). Sikap dalam memediasi hubungan kesadaran lingkungan dengan niat beli produk kosmetik ramah lingkungan. JMK, 17(2), 177-185. ISSN 1411-1438 print/ISSN 2338-8234, doi: 10.9744/jmk.17.2.177-185

Muslim, E., \& Indriani, D. R. (2014). Analisis pengaruh eco-label terhadap kesadaran konsumen untuk membeli green product. Jurnal Manajemen Teknologi, 13(1), 66-80.

Gustyanita, P. (2013). AQUA Group: berpedoman pada ater ground policy. Retrieved 8 April 2017, from http://swa.co.id/headline/aqua-group-berpedomanpada-water-ground-policy/Waskito, J., \& Witono, B. (2014). Model meningkatkan niat beli produk hijau: Sebuah pendekatan strategik. Jurnal Ekonomi dan Bisnis, XVII(3), 1-16. ISSN: 1979-6471.Ščypa, P. (2006). Lingkungan pemasaran dan povedenie potrebitelskoe/Russian markets. Ekonomi dan Manajemen: Current Issues and Perspectives, 2(7), 156-159.

Laroche, M., Bergeron, J., \& Babaro-Forleo, G. (2001). Targeting consumers who are willing to pay more for environmentally friendly products. Journal of Consumer Marketing, 18(6), 503-520.

Santoso, I., \& Fitriyani, R. (2016). Green packaging, green product, green advertising, persepsi. Jur. Ilm. Kel. \& Kons., 9(2), 148-158. ISSN: 1907-6037, e-ISSN: 2502-3594.Putra, I. P. A. S. S., \& Suryani, A. (2016). Peran green trust dalam memediasi pengaruh green perceived value terhadap green purchase behavior. Jurnal Manajemen, Strategi Bisnis dan Kewirausahaan, 10(1), 42-51.

Astuti, M., \& Yani, M. (2016). Pengaruh green marketing, lingkungan dan kesehatan terhadap keputusan pembelian melalui minat membeli produk organik (studi pada Hero Supermarket Sidoarjo). Prosiding Seminar Nasional Ekonomi dan Bisnis \& Call For Paper FEB UMSIDA, 336-351.

Algifari. (2015). Analisis regresi untuk bisnis dan ekonomi. Yogyakarta: BPFE.

Noor, J. (2015). Analisis data penelitian ekonomi dan manajemen (2nd ed.). Jakarta: Kompas Gramedia. Suprapti, N. W. S. (2010). Perilaku konsumen, pemahaman dasar dan aplikasinya dalam strategi 


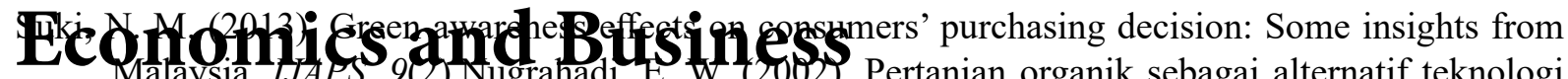

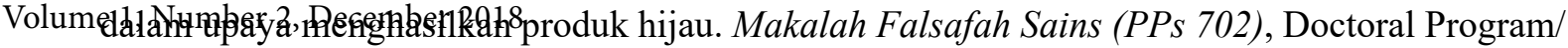
S3 IPB.

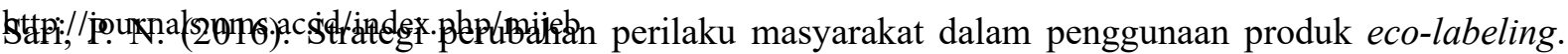
Seminar Nasional Sains dan Teknologi Lingkungan Padang, 19 Oktober 2016. II e-ISSN 25413880, 1-5. Retrieved 10 April 2017, from https:/goo.gl/MKu7eeAdil, A. (2015). Pengaruh pengetahuan tentang lingkungan, sikap pada lingkungan, dan norma subjektif terhadap niat pembelian green product. Jurnal Ekonomi dan Kewirausahaan, 15, 122-128.

Suherlan, Y. (n.d.). Model balai pengembangan kemasan ramah lingkungan untuk meningkatkan daya saing produk lokal UMKM pangan olahan menghadapi pasar global. Proceeding Seminar Nasional Peningkatan Kapabilitas UMKM dalam Mewujudkan UMKM Naik Kelas, 290-301. Retrieved 10 April 2017, from https://goo.gl/Aq4ZVd

Rath, R. C. (2013). An impact of green marketing on practices of supply chain management in Asia: Emerging economic opportunities and challenges. International Journal of Supply Chain Management, 2(1).Handayani, N. T. (2012). Pengaruh atribut produk terhadap loyalitas pelanggan green product sepeda motor honda injection. Management Analysis Journal, 1(2), 1-2.

D’Souza, C., Taghian, M., Lamb, P., \& Peretiatkos, R. (2006). Green products and coorporate strategy: An empirical investigation. Society and Business Review, 1(2).Herri, P, N., \& Kenedi, J. (2006). Analisis persepsi masyarakat terhadap produk hijau: tinjauan faktor demografi, psikologis, sosial dan budaya (kasus Kota Padang). Journal of Business \& Manajement, 2(1), 1-9.

Shrum, L., McCarty, J., \& Lowrey, T. (1995). Buyer characteristic of the green consumer and their implications for advertising strategy. Journal of Advertising, 24(2), 71-82. Desliana A., Gaffar, V., \& Andari, R. (2013). Pengaruh program green marketing di hotel Shangri-la Jakarta terhadap green consumer behavior. Journal of Tourism and Hospitality Essentials Anthology (THE Anthology), 1, 1-17.

Heri, P., N., \& Kenedi, J. (2006). Analisis persepsi masyarakat terhadap produk hijau: Tinjauan faktor demografi, psikologis, sosial dan budaya (kasus Kota Padang). Jurnal Business \& Manajemen, 2(1). 